\title{
Mono Lake radiocarbon puzzle blamed on nuclear waste disposal
}

Berkeley \& Washington

A Group of geochemists studying gas exchange in Mono Lake, California, has accidentally uncovered changes in radioactivity levels that suggest the lake may have been the site of clandestine nuclear waste disposal in the 1950s and $1970 \mathrm{~s}$

The research team, headed by Wallace Broecker of Columbia University's Lamont-Doherty Geological Observa. tory, found that radioactive carbon-14 levels in water samples from the lake jumped 15 per cent in the 1950 s and 5 per cent in the 1970s, a total of about 20 curies of radiocarbon. The increase is 15 times too great to be accounted for by fallout from atmospheric nuclear tests in nearby Nevada, says Broecker, and studies in two other Nevada lakes show no such discrepancies. After eliminating every known natural explanation for the jump in

\section{IMAGE UNAVAILABLE FOR COPYRIGHT REASONS}

remains that other radioactive elements entered the lake with the radiocarbon. especially if the rise was due to nuclear reactor or weapons waste. Broecker says his team plans to test core samples from the sediments at the bottom of the lake for radioactive caesium, strontium and other elements. Other Lamont-Doherty researchers found slightly elevated levels of plutonium in the lake. which they attributed to a high solubility in the lake's alkaline water. Broecker suggestes that their conclusion may need to be reevaluated in light of the carbon-14 discovery.

The percentage of carbon-14 in Mono lake carbon is naturally low, because hydrothermal vents in the lake are continually adding carbon dioxide that is completely free of carbon-14. Even with the mysteriously added radiocarbon, the carbon-14 to carbon-12 ratio in the lake is less than that in ocean water.

Broecker has been monitoring radiocarbon in the lake for more than 30 years, as part of a study of gas exchange. By 1972 he had noticed that radiocarbon levels in the lake had increased relative to his 1957 measurements very much faster than he expected. A possible explanation was that the lakes's unusual characteristics somehow increased the rate at which radiocarbon in the atmosphere, produced by nuclear bomb tests and reactors,

The distinctive tufa towers in Mono Lake. radiocarbon, Broecker finds himself left with the possibility that clandestine dumping of nuclear waste from government weapons tests is to blame.

Mono Lake, a highly saline lake with no outlet, has been the subject of controversy over its drop in water level, due to diversion of its feeder streams to provide drinking water for Los Angeles. The lake, which has a salinity more than twice that of sea water, and a $\mathrm{pH}$ of 10 , has no fish, but its algae, brine flies and brine shrimp provide food for large populations of migrating birds. The lake is known for its calcium carbonate formations, called tufa towers, formed where calcium-rich spring water enters the carbonate-laden lake.

The 20 curies of radiocarbon estimated to have been added to the lake increased total radiocarbon by only 20 per cent, because the lake water is so carbon-rich, says Broecker. He stresses that the additional radiocarbon poses no threat to the lake ecology, and certainly not to humans, as the lake is used neither for drinking water nor recreation. But the possibility

entered the lake waters. But experiments with a inert chemical tracer, SF6, showed no abnormalities in the rate of gas exchange between lake and atmosphere. And although the high alkalinity of the lake water did enhance chemical uptake of carbon dioxide, it did not do so by nearly enough to explain the increased radiocarbon.

Broecker was able to chart the radiation discrepancy more accurately when he recently compared notes with Scott Stine, a graduate student at the University of California, Berkeley, who had been estimating carbon-14 levels in the lake by sampling the calcium carbonate buildup on pebbles and wood along the steadily receding lake shore. Pebbles collected from the 1919 and 1938-47 shorelines, confirmed that there had been a massive increase in radiocarbon sometime after the Second World War, strongly suggestive of clandestine disposal of radioactive waste.

Broecker's first guess was that "the graphite from the World War II Univer- sity of Chicago graphite reactor" was a candidate. Some uncertaintly does surround the fate of Chicago Pile Number One (CP1), with which Enrico Fermi first demonstrated that a nuclear chain reaction could take place. Its 750,000 pounds of pure graphite was moved out to the site of what is now Argonne National Laboratory in 1943. Some small (and nonradioactive) pieces of the graphite ended up, encased in lucite, as souvenirs for those who worked on the project. Oldtimers at Argonne are not certain what happened to the rest. but believe that it went for reprocessing to Oak Ridge National Laboratory sometime in the 1950s. A Department of Energy spokes-

\section{Danger from Mono Lake water level}

\section{Washington}

A separate report, commissioned by the California Department of Fishing and Game from the University of California, Santa Barbara, charts the future of Mono Lake.

Since 1940, Los Angeles has been taking some 17 per cent of its water needs from the streams that flow into Mono Lake. As a result, the level of the lake has fallen 45 feet, its volume has halved and its salinity has doubled.

If water continues to be taken at the present rate, many of its distinctive tufa towers and substantial parts of the gull habitat will be endangered by 1991. By 2000 , bird life will disappear and later in the next century Mono Lake will become another Dead Sea. Los Angeles will need to cut its water imports from the area by almost half to keep the lake as it is.

Alun Anderson man dismissed the possibility that the Chicago graphite could have been transported across to Mono Lake as "ludicrous".

Additional data analysis by Broecker and his team has in any case shifted the first influx to a later date than first thought, between 1952 and 1957. By that time numerous bomb and reactor programmes were under way.

Military tests by the US Navy were even carried out in Mono Lake itself during the $1950 \mathrm{~s}$. But residents around the lake at the time were told the explosive tests were non-nuclear in nature, according to Emily Strauss, of the Mono Lake Committee. Navy and weapons laboratory officials have denied any responsibility for the elevated radiocarbon levels. Broecker hopes that publishing his results may encourage someone to come forward with an cxplanation - natural or unnatural -. for the mystery.

Marcia Barinaga \& Alun Anderson 